\title{
Biochemical Comparison of Pili from Variants of Neisseria gonorrhoeae P9
}

\author{
By PAUL R. LAMBDEN \\ Department of Microbiology, University of Southampton Medical School, Southampton General \\ Hospital, Southampton SO9 $4 X Y$, U.K.
}

(Received 1 December 1981; revised 19 February 1982)

\begin{abstract}
Four different types of pili produced by variants of Neisseria gonorrhoeae P9 were isolated and characterized. The pili differed in subunit molecular weight with SDS-PAGE and in subunit isoelectric point on agarose gels. Isoelectric points of the major molecular species in Tritonagarose gels of octylglucoside solubilized pili were: $\delta$, pI $6.5 ; \alpha, \mathrm{pI} 6.0 ; \beta, \mathrm{pI} 5 \cdot 3$ and $\gamma, \mathrm{pI} 5 \cdot 5$. Amino acid analyses of pili showed close homology between different types but a reduction in the content of aspartate and serine was notable in the low molecular weight $\delta$ pili; also $\beta$ and $\gamma$ pili contained more alanine residues. Structural homology was also demonstrated in peptide maps of tryptic/chymotryptic digests of pili with several major peptides apparently common to all four pilus types.
\end{abstract}

\section{INTRODUCTION}

Gonococci produce filamentous protein pili which are probably important determinants of virulence mediating adhesion to host cells (Buchanan, 1977; Swanson, 1973) and preventing the phagocytosis of virulent gonococci by human polymorphonuclear leukocytes (Dilworth et al., 1975; Ofek et al., 1974). The loss of pili by non-selective subculture on laboratory media indicates that the host exerts a strong selective pressure on gonococci to produce pili. Amino acid composition, subunit molecular weights and antigenic differences in pili (Brinton et al., 1978; Buchanan et al., 1978; Robertson et al., 1977) suggest a wide variation in pilus types amongst different strains of $N$. gonorrhoeae. Indeed, the P9 strain of $N$. gonorrhoeae produces two distinct pilus types designated $\alpha$ and $\beta$ (Lambden et al., 1980, 1981 b). These two types of pili differ in subunit molecular weight, isoelectric point, buoyant density and amino acid composition, as well as in their ability to bind to human buccal epithelial cells. The production of different pili by opaque and transparent colonial variants of a single gonococcal strain has also been reported by Salit $e t$ al. (1980). However, it has now become apparent from studies with in vivo-grown organisms that a single strain of gonococcus is capable of even wider pilus variation. Two further pilus types, designated $\gamma$ and $\delta$, were found in variants of strain P9 recovered from guinea-pig subcutaneous chambers (Lambden et al., 1981 a). The two new pilus types differed from $\alpha$ and $\beta$ pili in subunit molecular weight. The ability to produce four different types of pili suggested that the gonococcus is capable of varying the properties of its surface in reply to the immune response mounted by the host. A biochemical analysis of the pilus types produced by $N$. gonorrhoeae $\mathrm{P9}$ is presented in this paper.

\section{METHODS}

Bacterial strains and growth conditions. Neisseria gonorrhoeae P9 variants P9-2 ( $\alpha$ pili), P9-20 ( $\beta$ pili), P9-27 ( $\gamma$ pili) and P9-32 ( $\delta$ pili) (Lambden et al., $1981 a$ ) were grown at $36{ }^{\circ} \mathrm{C}$ in an atmosphere of $5 \%(\mathrm{v} / \mathrm{v}) \mathrm{CO}_{2}$ on a clear typing medium with the following composition $\left(\mathrm{g}^{-1}\right.$ ): Agar (Oxoid no. 1), 10; proteose peptone no. 3 (Difco), 10; soluble starch $(\mathrm{BDH}) 1 ; \mathrm{K}_{2} \mathrm{HPO}_{4}, 4 ; \mathrm{KH}_{2} \mathrm{PO}_{4}, 1 ; \mathrm{NaCl}, 5$ and a supplement similar in composition to Isovitalex (BBL) except that L-cystine was omitted (Lambden et al., 1979). Stock cultures were stored in liquid $\mathrm{N}_{2}$ as previously described (Lambden \& Heckels, 1979). Pilated colonial variants were picked and purified by single colony 
isolation on typing medium prior to large scale batch cultures on trays $(27 \times 38 \mathrm{~cm})$ of GC base (Difco) containing the same supplement as that used in typing medium.

Preparation of pili. Gonococcal pili were prepared essentially as described by Brinton et al. (1978). Gonococci were scraped from the agar surface into ice-cold ethanolamine $/ \mathrm{HCl}(0.15 \mathrm{M}, \mathrm{pH} 10.5)$ and subjected to mild shearing in a vortex mixer (P. Silver, Hampton, Middx) for $2 \mathrm{~min}$. The organisms were removed by centrifugation at $23000 \mathrm{~g}$ for $30 \mathrm{~min}$, and the pili were precipitated from the supernatant fluid by addition of saturated ammonium sulphate solution to give a final saturation of $10 \%$. Pili were recovered by centrifugation at $10000 \mathrm{~g}$ for $1 \mathrm{~h}$ and purified by further cycles of disaggregation in ethanolamine buffer and precipitation with ammonium sulphate. Pili were finally washed in $1 \mathrm{M}-\mathrm{NaCl}$ and stored at $4{ }^{\circ} \mathrm{C}$ in $1 \mathrm{M}-\mathrm{NaCl}$ containing $8 \mathrm{mM}-\mathrm{NaN}_{3}$. The purity of each pilus preparation was assessed by SDS-PAGE as described below.

$S D S-P A G E$. Samples ( $25 \mu \mathrm{g}$ protein) were subjected to SDS-PAGE using the discontinuous buffer system of Laemmli (1970), and a slab gradient acrylamide system described by Heckels (1981). Pilus proteins were resolved on a linear concentration gradient of 10 to $25 \%(\mathrm{w} / \mathrm{v})$ acrylamide. Gels $(170 \times 130 \times 1.4 \mathrm{~mm})$ were run at $200 \mathrm{~V}$ for $20 \mathrm{~h}$ at $4^{\circ} \mathrm{C}$.

Agarose gel isoelectric focusing (IEF). Isoelectric focusing of pilus samples was performed in horizontal agarose slab gels $(125 \times 110 \times 0.9 \mathrm{~mm})$ cast on sheets of Gel Bond (Miles, Stoke Poges, Slough). Gels were of the following composition : $0.8 \%(\mathrm{w} / \mathrm{v})$ agarose (Agarose $\left.\mathrm{EF}-\mathrm{m}_{\mathrm{r}}=0.005, \mathrm{LKB}\right), 10 \%(\mathrm{w} / \mathrm{v})$ sorbitol, $1 \%(\mathrm{v} / \mathrm{v})$ Triton X-100, $2 \%$ $(\mathrm{w} / \mathrm{v})$ ampholytes (Ampholine $\mathrm{pH} 3 \cdot 5-9.5, \mathrm{LKB})$. The electrode solutions were $0.5 \mathrm{M}-\mathrm{NaOH}$ and $0.2 \mathrm{M}$-lactic acid. Samples of purified pili in $1 \mathrm{M}-\mathrm{NaCl}$ were sedimented by centrifugation and the pellet solubilized to give a final concentration of $5 \mathrm{mg} \mathrm{ml}^{-1}$ in a $1 \%(\mathrm{w} / \mathrm{v})$ aqueous solution of the neutral detergent $n$-octyl glucoside (Sigma). Samples $(2$ to $4 \mu \mathrm{l})$ of solubilized pili were applied to small squares of filter paper $(5 \times 5 \mathrm{~mm})$ placed directly on the gel surface approximately $3 \mathrm{~cm}$ from the anode wick. Gels were cooled to $8^{\circ} \mathrm{C}$ and were run on an LKB Multiphor apparatus at a constant $6.5 \mathrm{~W}$ for about $70 \mathrm{~min}$, or until a visual marker of haemoglobin was sharply focused. When focusing was complete a strip of agarose was cut from one edge of the gel and sectioned at $5 \mathrm{~mm}$ intervals. Agarose sections were placed in boiled, de-gassed water for determination of the $\mathrm{pH}$ gradient across the gel. The IEF gel was fixed in a solution containing (per litre): $115 \mathrm{~g}$ trichloroacetic acid, $35 \mathrm{~g}$ sulphosalicyclic acid, $300 \mathrm{ml}$ methanol and water added to 1 litre. At this stage the gel became opaque due to the insolubility of Triton X-100 in the fixative. The gel was cleared in $95 \%(\mathrm{v} / \mathrm{v})$ ethanol, pressed and dried in a stream of warm air before staining in ethanol/acetic acid/water ( $35: 10: 55$, by vol) containing $0 \cdot 5 \%$ (w/v) Kenacid Blue R (BDH). Destaining was in the same solvent except that Kenacid Blue was omitted.

Radiolabelling of pili and peptide mapping. Purified pili were $S$-carboxymethylated with iodoacetic acid as previously described (Lambden et al., 1981b), dialysed against $0.4 \%(\mathrm{w} / \mathrm{v}) \mathrm{NH}_{4} \mathrm{HCO}_{3}$ and freeze-dried. $S$ Carboxymethylated pili $(1 \mathrm{mg})$ were dissolved in $100 \mu \mathrm{l}$ of $N$-ethylmorpholine/acetic acid buffer $(0 \cdot 1 \mathrm{M}, \mathrm{pH} 9 \cdot 0)$ containing $4 \mathrm{M}$-guanidine $/ \mathrm{HCl}$ and added to a tube containing $0.5 \mathrm{mCi}(18.5 \mathrm{MBq})$ of methyl $3,5-$ di[ ${ }^{125}$ I] iodohydroxybenzimidate (Amersham) (Wood et al., 1975). The methanol solvent was removed from the iodinating agent in a stream of $\mathrm{N}_{2}$ before addition of the pili. The amidination reaction was allowed to proceed for $48 \mathrm{~h}$ at $37^{\circ} \mathrm{C}$ before exhaustive dialysis of the reaction products against $0.4 \%(\mathrm{w} / \mathrm{v}) \mathrm{NH}_{4} \mathrm{HCO}_{3}$ and freeze-drying. The iodinated imidoester derivatives of $S$-carboxymethylated pili $(1 \mathrm{mg})$ were dissolved in $500 \mu \mathrm{l}$ of $0.4 \%(\mathrm{w} / \mathrm{v})$ $\mathrm{NH}_{4} \mathrm{HCO}_{3}$ and treated with $20 \mu \mathrm{g}$ trypsin (Sigma type III) for $4 \mathrm{~h}$ at $37^{\circ} \mathrm{C}$ followed by $20 \mu \mathrm{g} \alpha$-chymotrypsin (Sigma type II) and the mixture was allowed to incubate at $37^{\circ} \mathrm{C}$ for a further $16 \mathrm{~h}$. The tryptic/chymotryptic digests were freeze-dried and re-dissolved in $0.05 \mathrm{M}-\mathrm{NH}_{3}$ before spotting samples (approximately $10^{5} \mathrm{~d} . \mathrm{p} . \mathrm{m}$.) on to silica gel TLC plates $(10 \times 10 \mathrm{~cm}$; Polygram SilG, Macherey-Nagel, Duren, F.R.G.). Peptides were resolved by electrophoresis ( $250 \mathrm{~V}$ for $60 \mathrm{~min}$ ) at $\mathrm{pH} 3.5$ (pyridine/acetic acid/water; $1: 10: 189$, by vol.) in the first dimension followed by ascending chromatography ( $n$-butanol/pyridine/acetic acid/water; $15: 10: 3: 12$, by vol.) in the second dimension (Bates et al., 1975; Lambden $e t$ al., 1981b). Radioactive peptides were detected by autoradiography with Kodak X-Omat H film exposed for $24 \mathrm{~h}$.

Amino acid analysis. Samples ( 25 to $100 \mu \mathrm{g}$ dry weight protein) of purified pili were dialysed against distilled water and hydrolysed under vacuum in $3 \mathrm{M}$-mercaptoethanesulphonic acid (Lambden et al., 1981 b; Penke et al., 1974) for $24 \mathrm{~h}$ at $110^{\circ} \mathrm{C}$. Acid hydrolysates were neutralized with $3 \mathrm{M}-\mathrm{NaOH}$ prior to analysis on a Rank Hilger Chromaspek amino acid analyser (Margate, Kent). Amino acid recoveries were corrected for by parallel hydrolyses of purified egg white lysozyme. The overall amino acid composition was determined from six independent hydrolyses of two preparations of each pilus type.

\section{RESULTS}

\section{$S D S-P A G E$}

Highly purified $\delta, \alpha, \beta$ and $\gamma$ pili were clearly distinguishable by differences in their apparent subunit molecular weights $(18500 ; 19500 ; 20500$ and 21000 , respectively) (Fig. 1) as described previously (Lambden et al., 1981a). However, staining with Kenacid Blue and the use of 


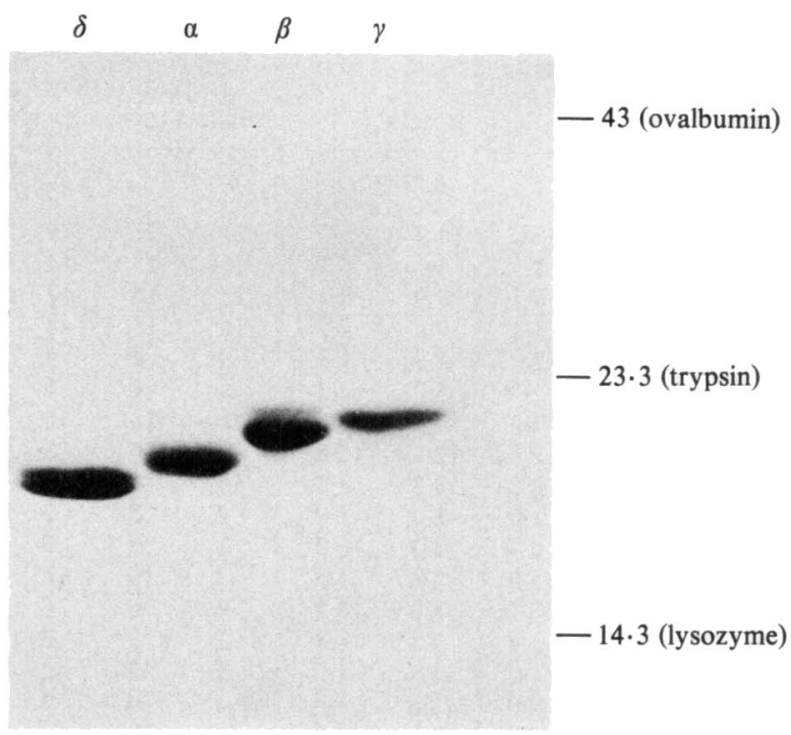

Fig. 1. SDS-PAGE of purified pili from variants of $N$. gonorrhoeae P9. Gels were loaded with $25 \mu \mathrm{g}$ protein to estimate the purity of each preparation. The positions of three standard proteins (kDal) are indicated.

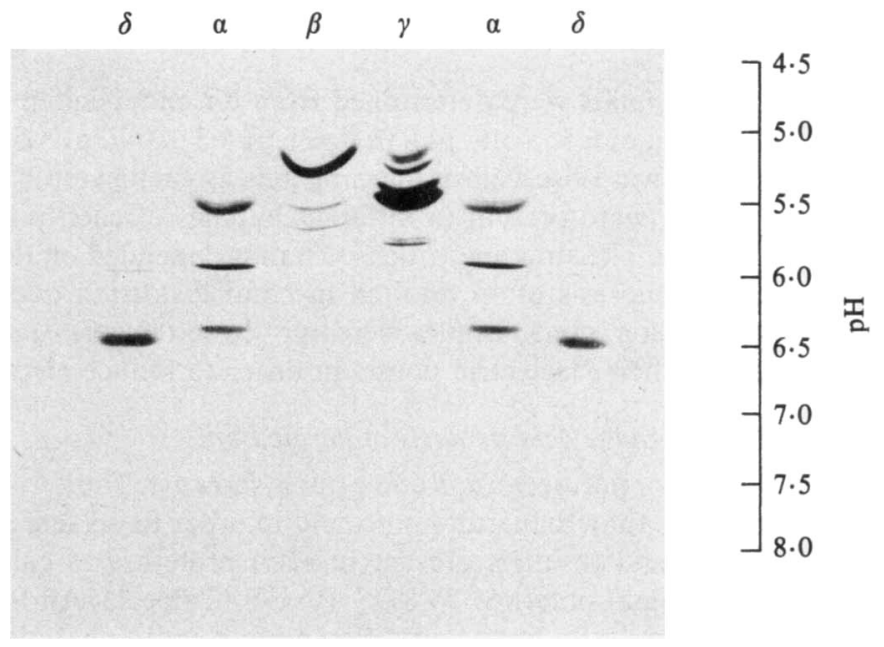

Fig. 2. Agarose-IEF of purified pili from variants of $N$. gonorrhoeae P9. Pili were solubilized in $1 \%$ $(\mathrm{w} / \mathrm{v})$ octyl glucoside and subjected to isoelectric focusing in $0.8 \%(\mathrm{w} / \mathrm{v})$ agarose gels containing $1 \%$ Triton X-100.

gradient acrylamide gels revealed some heterogeneity in pilus bands. In particular, the $\alpha$ and $\beta$ pilus bands were always accompanied by a minor band of slightly higher molecular weight which was impossible to eliminate by further cycles of pilus purification (Fig. 1), and occasionally $\delta$ pili were also partially resolved into two bands of very similar subunit molecular weights. No contamination of pilus preparations by other proteins was observed when gels were loaded with $25 \mu \mathrm{g}$ protein, indicating a purity of $>99 \%$.

\section{Agarose gel isoelectric focusing}

Each pilus type was completely solubilized by the detergent $n$-octyl glucoside. Detergentsolubilized pili were resolved into sharply focused bands as shown in Fig. 2. Again different pili were distinct from each other and focused into one major and several minor bands. The 
Table 1. Amino acid analysis of gonococcal pili

\begin{tabular}{|c|c|c|c|c|c|c|c|c|}
\hline \multirow[t]{2}{*}{ Amino acid } & \multicolumn{4}{|c|}{$\mathrm{Mol} \%$ of protein } & \multicolumn{4}{|c|}{$\begin{array}{c}\text { Integral residues per } \\
\text { subunit molecular weight }\end{array}$} \\
\hline & $\delta$ & $\alpha$ & $\beta$ & $\gamma$ & $\delta$ & $\alpha$ & $\beta$ & $\gamma$ \\
\hline Asx ${ }^{\dagger}$ & $12 \cdot 3$ & $15 \cdot 0$ & $14 \cdot 9$ & $15 \cdot 8$ & 21 & 27 & 29 & 31 \\
\hline Thr & $7 \cdot 5$ & $7 \cdot 3$ & $5 \cdot 7$ & $5 \cdot 7$ & 13 & 13 & 11 & 11 \\
\hline Ser & $5 \cdot 7$ & $8 \cdot 7$ & 8.9 & $8 \cdot 6$ & 10 & 16 & 17 & 17 \\
\hline Glxt & $8 \cdot 6$ & $8 \cdot 4$ & $9 \cdot 4$ & $7 \cdot 9$ & 14 & 15 & 18 & 15 \\
\hline $\operatorname{Cys}\left(\frac{1}{2}\right)$ & $2 \cdot 1$ & $2 \cdot 0$ & 1.9 & $1 \cdot 8$ & 4 & 4 & 4 & 4 \\
\hline Pro & $2 \cdot 9$ & $2 \cdot 4$ & $3 \cdot 0$ & $2 \cdot 2$ & 5 & 4 & 6 & 4 \\
\hline Gly & $9 \cdot 4$ & $7 \cdot 4$ & $7 \cdot 3$ & $6 \cdot 0$ & 16 & 13 & 14 & 12 \\
\hline Ala & $11 \cdot 7$ & $10 \cdot 8$ & $12 \cdot 8$ & $12 \cdot 6$ & 20 & 20 & 25 & 24 \\
\hline Val & 9.4 & $8 \cdot 5$ & $8 \cdot 3$ & 8.9 & 16 & 15 & 16 & 17 \\
\hline Met & $1 \cdot 1$ & $1 \cdot 0$ & $1 \cdot 0$ & $1 \cdot 0$ & 2 & 2 & 2 & 2 \\
\hline Ile & $4 \cdot 6$ & $4 \cdot 5$ & $4 \cdot 3$ & $5 \cdot 3$ & 8 & 8 & 8 & 10 \\
\hline Leu & $5 \cdot 4$ & $5 \cdot 3$ & $5 \cdot 4$ & $5 \cdot 5$ & 9 & 10 & 10 & 11 \\
\hline Tyr & $3 \cdot 4$ & $3 \cdot 1$ & $3 \cdot 0$ & $3 \cdot 2$ & 6 & 6 & 6 & 6 \\
\hline Phe & 1.0 & 1.4 & 0.8 & 0.8 & 2 & 3 & 2 & 2 \\
\hline His & $1 \cdot 3$ & $1 \cdot 2$ & 0.8 & $1 \cdot 2$ & 2 & 2 & 2 & 2 \\
\hline Trp & $2 \cdot 2$ & $2 \cdot 0$ & 1.8 & 1.9 & 4 & 4 & 4 & 4 \\
\hline Lys & 8.7 & $8 \cdot 2$ & 8.0 & $8 \cdot 0$ & 15 & 15 & 16 & 16 \\
\hline Arg & $2 \cdot 8$ & 2.7 & $2 \cdot 5$ & $3 \cdot 2$ & 5 & 5 & 5 & 6 \\
\hline
\end{tabular}

* Subunit molecular weights as estimated by SDS-PAGE were taken to be 18500, 19500, 20500 and 21000 for $\delta, \alpha, \beta$ and $\gamma$ pili, respectively.

† Asx, Aspartic acid or Asparagine; Glx, Glutamic acid or glutamine.

isoelectric points of the major bands were determined from ten independent focusing experiments and were as follows: $\delta$ pili, pI $6.5 ; \alpha$ pili, pI $6.0 ; \beta$ pili, pI $5 \cdot 3 ; \gamma$ pili, pI $5 \cdot 5$. Isoelectric point heterogeneity of pilus samples was observed in focusing gels as each sample gave a variety of charged species (Fig. 2) which were present in different batches of each pilus type.

The resolution of the pilus samples into finely focused bands depended on the sample loading position, as prolonged electrophoresis often resulted in band distortion due to the effects of electroendosmosis. For this reason, pilus samples were applied to the gel at positions in the $\mathrm{pH}$ gradient which were close to their isoelectric points in order to reduce electrophoresis time.

\section{Amino acid analysis of purified pili}

The amino acid composition of purified $\delta, \alpha, \beta$ and $\gamma$ pili is shown in Table 1. Samples were hydrolysed under vacuum in mercaptoethanesulphonic acid in order to preserve tryptophan residues. The number of amino acid residues present in each protein was calculated from the apparent subunit molecular weight obtained by SDS-PAGE (Table 1). All four pilus proteins showed considerable overall similarity but some differences in individual amino acid content were seen. The content of aspartate/asparagine and serine was substantially reduced in the low molecular weight $\delta$ pili, whereas the content of the other amino acids was essentially the same as the other pilus proteins. Repeat analyses consistently showed that $\alpha$ pili contained one extra phenylalanine residue and that the higher molecular weight $\beta$ and $\gamma$ pili contained a greater number of alanine residues. Other minor differences in content of individual amino acids were seen, but were not as reproducible as the ones described above.

\section{Peptide maps of different pilus variants}

The structural relationship between the different forms of pilin was further examined by two dimensional peptide mapping of tryptic/chymotryptic hydrolysis products from radiolabelled $S$ carboxymethylated pili. Chymotrypsin was used together with trypsin to increase the number of peptides since modification of the lysine residues results in resistance to cleavage with trypsin (Bates et al., 1975). The lysine residues of pili were labelled to a high specific activity $[0.5 \mu \mathrm{Ci}(\mu \mathrm{g}$ protein $)^{-1}, 50 \%$ incorporation of label] with methyl 3,5-di[ $\left.{ }^{125} \mathrm{I}\right]$ iodohydroxybenzimidate in the presence of $4 \mathrm{M}$-guanidine $/ \mathrm{HCl}$ at $\mathrm{pH} 9 \cdot 0$. Autoradiographs of peptide maps are shown in Fig. 3 


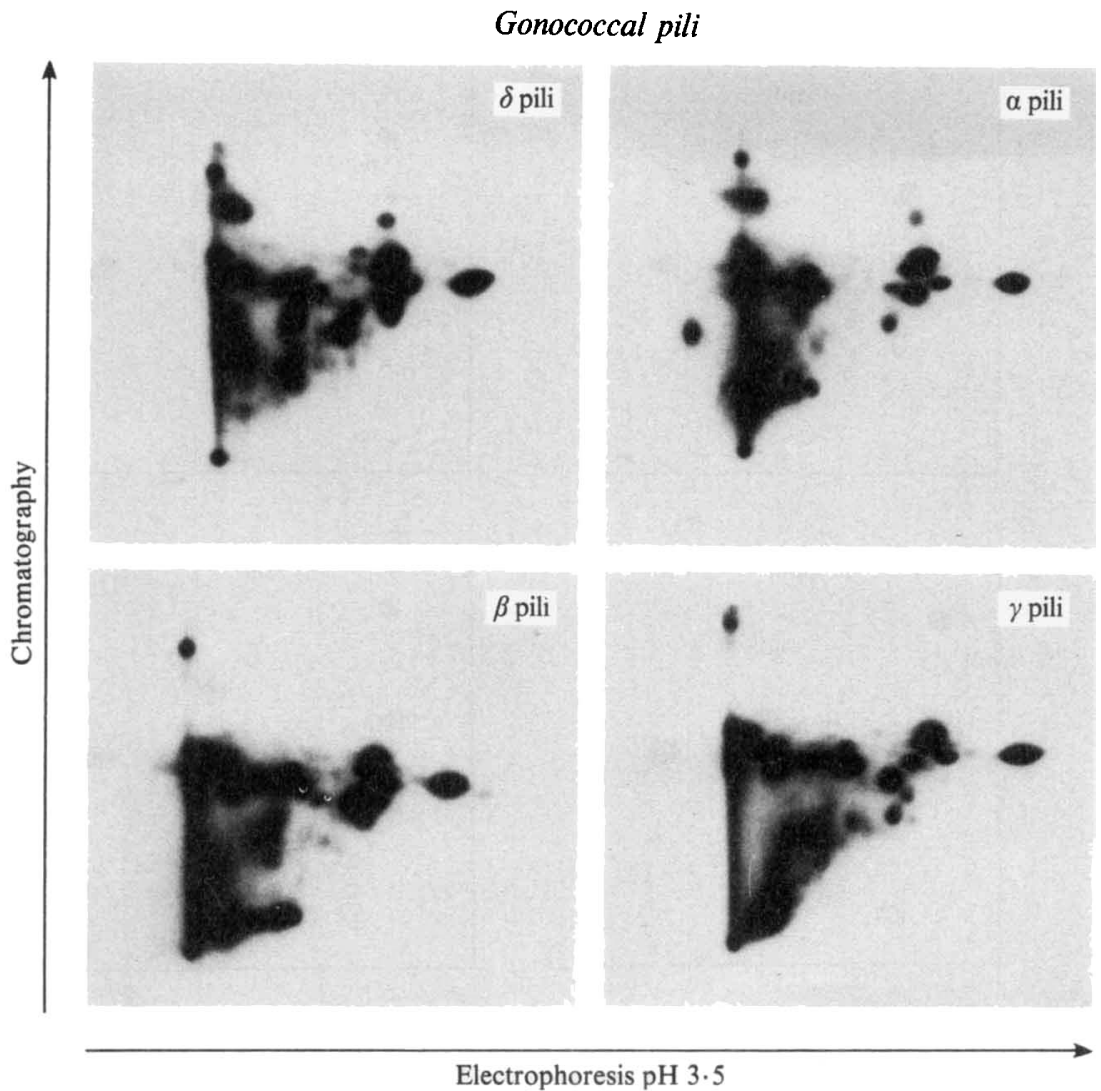

Fig. 3. Autoradiographs of ${ }^{125}$ I-labelled peptides obtained by two-dimensional peptide mapping of tryptic/chymotryptic hydrolysates of pili on silica gel thin-layer plates. For details see Methods.

and composite drawings of five independent analyses are shown in Fig. 4. Inspection of the autoradiographs reveal rather more spots than would be predicted from the number of lysine residues obtained by amino acid analysis and presumably reflects the presence of some partial digestion products. Pili showed a high degree of structural homology with nine of the major spots common to all four types of pili (Fig. 4). However, direct comparison of the peptide maps suggested that certain peptides were found only in $\delta$ and $\alpha$ pili, whereas other peptides appeared to be common only to $\beta$ and $\gamma$ pili indicating some structural relationship between $\alpha$ and $\delta$ pili and between $\beta$ and $\gamma$ pili. Each of the four pilus types produced a number of radioactive peptides which were unique to that particular pilus. Some of the peptides were more heavily radiolabelled than others which presumably reflected the different content of lysine residues in each of the peptides or the efficiency of labelling a particular lysine residue.

\section{DISCUSSION}

Neisseria gonorrhoeae $\mathrm{P9}$ is capable of producing a variety of pilus types (Lambden et al., $1981 a$ ) presumably in response to changes in environment in vivo. A detailed analysis of these different pili may lead to an understanding of the structural relationship between the pili and the molecular basis for this variation. Analysis of pilus substructure by SDS-PAGE and agarose IEF revealed some heterogeneity within pilus types. In particular multiple bands were seen in isoelectric focusing gels, each pilus type showing a variety of charged species. These different molecular species could be due to a variable content of carbohydrate or phosphate (Robertson et al., 1977) in pilin subunits or due to changes in net charge on pilus subunits caused by deamidation of glutamine or asparagine residues during preparation of the pili. Another possibility is that pili are modified in vivo during their synthesis or modified subsequently as a result of post translational processes such as that seen with alkaline phosphatase (Chang et al., 1980). 


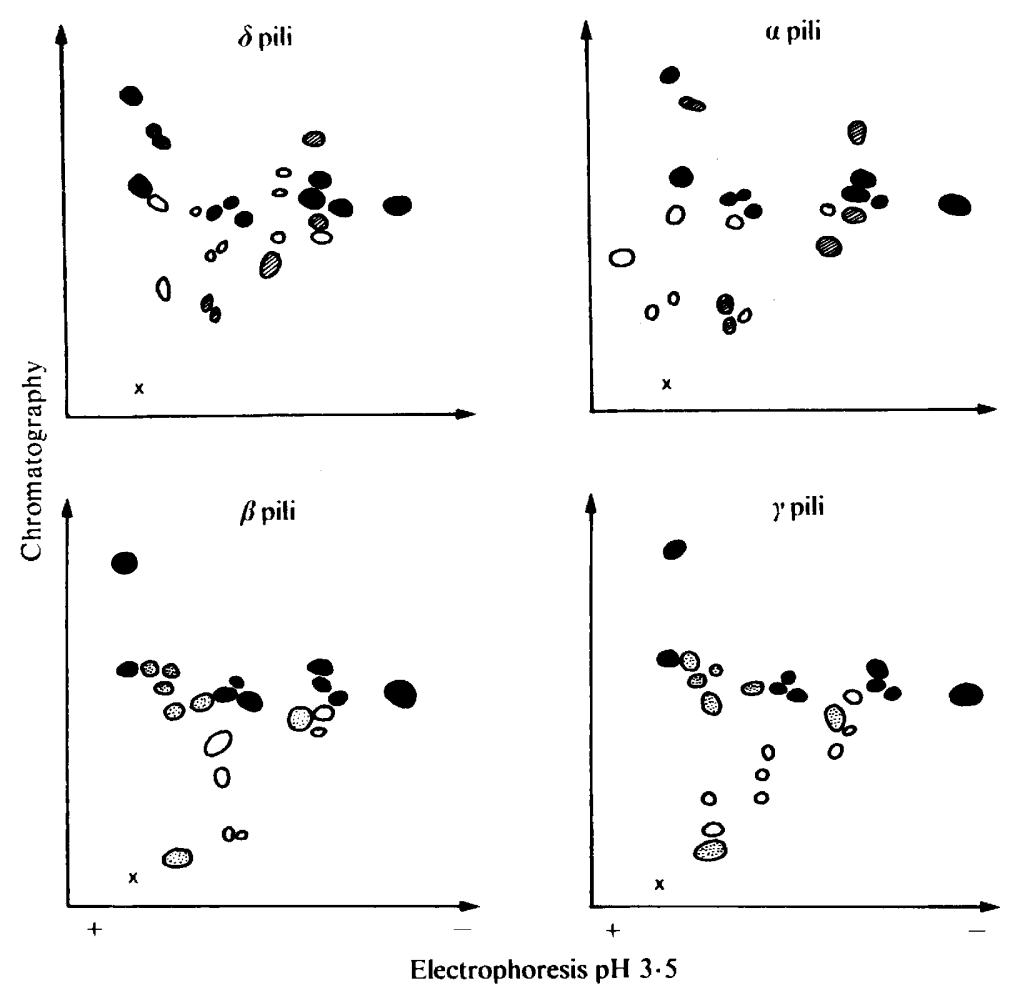

Fig. 4. Diagrammatic representation of autoradiographs of peptide maps. Maps are composites of five independent analyses. Peptides which were common to all four pilus types are shown as solid spots; peptides common to $\delta$ and $\alpha$ pili are shown as cross-hatched spots; and peptides common to $\beta$ and $\gamma$ pili are shown as dotted spots. The open spots represent peptides which appear to be unique to individual pilus types. Some of the faint spots were not always seen in replicate mapping experiments and consequently were not represented in the composite drawings.

Indeed it has been shown that about $50 \%$ of the pilus subunits found in gonococci lack an $\mathrm{N}$ terminal $N$-methyl phenylalanine (Hermodson et al., 1978).

The agarose IEF system gave better resolution than polyacrylamide gels. Pili were readily soluble in the non-ionic detergent $n$-octyl glucoside and the resulting molecular species migrated through a gel containing $1 \%$ Triton X-100. Attempts to solubilize pili in Triton X-100 or Nonidet P40 were unsuccessful as the pili failed to migrate through the agarose gel. The use of a neutral detergent to preserve intrinsic charge on the protein to be focused is an advantage over those systems which rely on the use of urea combined with a strongly ionic detergent such as SDS (Salit et al., 1980). However, the $\mathrm{pI}$ values obtained for the major bands of $\alpha$ and $\beta$ pili were somewhat higher than the values previously obtained by sucrose density gradient-IEF of intact pili (Lambden $e t a l ., 1981 \mathrm{~b}$ ). This is possibly a consequence of disaggregation of pili into subunits in the presence of detergent, resulting in the exposure or alteration of ionizable groups.

The existence of a structural relationship between the various forms of pili was suggested by the high degree of molecular structural homology seen in the amino acid composition and peptide maps. The differences in content of aspartic residues may in part contribute to the observed differences in isoelectric point in agarose gels. Analysis of the tryptic/chymotryptic hydrolysis products of pili modified by radioiodination of the lysine residues revealed that a number of major peptides were common to all four pilus proteins. Moreover, the peptide maps suggested structural similarities common to $\delta$ and $\alpha$ pili and structural similarities common to $\beta$ and $\gamma$ pili. This observation may in some way reflect the significantly increased content of alanine found in both $\beta$ and $\gamma$ pili.

A high degree of structural homology has also been observed in the group of outer membrane 
proteins (proteins II) associated with colonial opacity variations of the gonococcus (Heckels, 1981).

The physiological and genetic basis for this phenotypic variation is not understood. The $\delta$ and $\gamma$ type pili arose from growth of strain P9 in vivo in guinea-pig subcutaneous chambers (Lambden et al., 1981 a) where there may have been some selective pressure on the organism which resulted in production of antigenically distinct pili. The rate of phenotypic change observed in vitro suggests that a process similar to flagellar phase variation (Kutsukake \& Iino, 1980) might occur. The capacity for rapid antigenic shift to meet changes in in vivo conditions probably confers an advantage for survival and may account for the success of this organism as a pathogen.

This work was supported by a Medical Research Council Programme Grant. I am grateful to Professor P. J. Watt for advice and encouragement and to Mrs J. S. Everson for skilled technical assistance.

\section{REFERENCES}

Bates, D. L., Perham, R. N. \& Coggins, J. R. (1975). Methods for obtaining peptide maps of proteins on a subnanomole scale. Analytical Biochemistry 68, 175184.

Brinton, C. C., Bryan, J., Dillon, J.-A., Guerina, N., JACOBSON, L. J., LABIK, A., LeE, S., LeVine, A., Lim, S., McMichael, J., Polen, S., Rogers, K., To, A. C.-C. \& To, S. C.-M. (1978). Uses of pili in gonorrhea control: role of bacterial pili in disease, purification and properties of gonococcal pili, and progress in the development of a gonococcal pilus vaccine for gonorrhea. In Immunobiology of Neisseria gonorrhoeae, pp. 145-154. Edited by G. F. Brooks, E. C. Gotschlich, K. K. Holmes, W. D. Sawyer \& F. E. Young. Washington, D.C.: American Society for Microbiology.

Buchanan, T. M. (1977). Surface antigens: pili. In The Gonococcus, pp. 255-272. Edited by R. B. Roberts. New York: John Wiley.

Buchanan, T. M., Pearce, W. A. \& Chen, K. C. S. (1978). Attachment of Neisseria gonorrhoeae pili to human cells, and investigations of the chemical nature of the receptor for gonococcal pili. In Immunobiology of Neisseria gonorrhoeae, pp. 242-249. Edited by G. F. Brooks, E. C. Gotschlich, K. K. Holmes, W. D. Sawyer \& F. E. Young. Washington, D. C.: American Society for Microbiology.

Chang, C. N., Inouye, H., Model, P. \& Beckwith, J. (1980). Processing of alkaline phosphatase precursor to the mature enzyme by an Escherichia coli inner membrane preparation. Journal of Bacteriology 142, 726-728.

Dilworth, J. A., Hendley, J. O. \& MANDell, G. L. (1975). Attachment and ingestion of gonococci by human neutrophils. Infection and Immunity 11, 512516.

HeCKels, J. E. (1981). Structural comparison of Neisseria gonorrhoeae outer membrane proteins. Journal of Bacteriology 145, 736-742.

Hermodson, M. A., Chen, K. C. S. \& Buchanan, T. M. (1978). Neisseria pili proteins: amino terminal amino acid sequences and identification of an unusual amino acid. Biochemistry 17, 442-445.

KuTSUKAKE, K. \& IINO, T. (1980). A trans-acting factor mediates inversion of a specific DNA segment in flagellar phase variation of Salmonella. Nature, London 284, 479-481.
LAEMMLI, U. K. (1970). Cleavage of structural proteins during the assembly of the head of bacteriophage T4. Nature, London 227, 680-685.

LAMBdEN, P. R. \& HeCkels, J. E. (1979). The influence of outer membrane protein composition on the colonial morphology of Neisseria gonorrhoeae strain P9. FEMS Microbiology Letters 5, 263-265.

LAmbden, P. R., Heckels, J. E., JaMes, L. T. \& WATT, P. J. (1979). Variations in surface protein composition associated with virulence properties in opacity types of Neisseria gonorrhoeae. Journal of General Microbiology 114, 305-312.

Lambden, P. R., Robertson, J. N. \& Watt, P. J. (1980). Biological properties of two distinct pilus types produced by isogenic variants of Neisseria gonorrhoeae P9. Journal of Bacteriology 141, 393-396.

Lambden, P. R., Heckels, J. E., McBride, H. \& WATT, P. J. (1981 a). The identification and isolation of novel pilus types produced by variants of $N$. gonorrhoeae $\mathrm{P9}$ following selection in vivo. FEMS Microbiology Letters 10, 339-341.

Lambden, P. R., Robertson, J. N. \& WatT, P. J. $(1981 b)$. The preparation and properties of $\alpha$ and $\beta$ pili from variants of Neisseria gonorrhoeae P9. Journal of General Microbiology 124, 109-117.

OFEK, I., BEACHEY, E. H. \& BISNO, A. L. (1974). Resistance of Neisseria gonorrhoeae to phagocytosis: relationship to colonial morphology and surface pili. Journal of Infectious Diseases 129, 310-316.

Penke, B., Ferenczi, R. \& Kovacs, K. (1974). A new acid hydrolysis method for determining tryptophan in peptides and proteins. Analytical Biochemistry 60, 45-50.

Robertson, J. N., VinCENT, P. \& WARD, M. E. (1977). The preparation and properties of gonococcal pili. Journal of General Microbiology 102, 169-177.

Salit, I. E., Blake, M. \& Gotschlich, E. C. (1980). Intrastrain heterogeneity of gonococcal pili is related to opacity colony variance. Journal of Experimental Medicine 151, 716-725.

Swanson, J. (1973). Studies on gonococcus infection. IV. Pili: their role in attachment of gonococci to tissue culture cells. Journal of Experimental Medicine 137, 571-589.

WOOD, F. T., Wu, M. M. \& Gerhart, J. C. (1975). The radioactive labelling of proteins with an iodinated amidination reagent. Analytical Biochemistry 69, 339-349. 